Олена БОГАТІКОВА,

orcid.org/0000-0002-9164-3524

аспірантка Маріупольського державного університету

(Україна, Маріуполь)lol9877@теta.ua

\title{
ІСТОРІЯ УКРАЇНСЬКОГО САКРАЛЬНОГО БУДІВНИЦТВА У ДОСЛІДЖЕННЯХ ГРИГОРІЯ ПАВЛУЦЬКОГО
}

У статті подано характеристику основних робіт Г. Павлуизкого, присвячених дерев'яному та кам'яному иерковному зодчеству південноруського регіону. Встановлено архітектурні пам'ятки, які потрапили у поле зору науковия. Вказано їх особливості, які привернули увагу дослідника: тип споруди, період будівництва. Акцентовано увагу на висновках, зроблених Г. Павлуцьким щуодо автентичного походження сакральної архітектури регіону та часу будівництва перших культових споруд. Наголошено на актуальності розвідок Г. Павлуцького для сучасної науки.

Ключові слова. Церковне зодчество, архітектура, храм, сакральна споруда.

Olena ВОНАTIKОVA,

Post-graduate student of Mariupil' State University, (Ukraine, Mariupil')lol9877@meta.ua

\section{THE HISTORY OF UKRAINIAN SACRAL CONSTRUCTION IN HRYHORIY PAVLUTSKYI'S STUDIES}

The article presents the characteristics of $H$. Pavlutskyi's main works on wooden and stone church architecture of the South-Russian region. The basic idea of the article is H. Pavlutskyi's conclusions about the authentic origin of the sacred architecture of the region and the time of construction of the first religious buildings there.

1899 was a landmark in the further scientific activity of the researcher, because at that time H. Pavlutskyi for the first time took part in the work of the XI Archaeological Congress in Kiev, which was, according to the researcher, an impetus for the arousal of attention and study of the remnants of the past of his native Ukraine.

As a true scholar and a passionate connoisseur of art, H. Pavlutskyi couldn't stay away from studying and, most importantly, preservation of the monuments of art of his homeland. His work at the scientific forum dramatically changed the researcher's scientific preferences which, in its turn, according to the author, influenced the further development of art science in Ukraine. The author notes that since that time, his main theme of scientific development becomes the Ukrainian architecture, especially, wooden church architecture.

It's worthy of note, that the researcher investigated and analyzed the church objects of the XVII-beginning of the XIX centuries in Kiev, Cherkasy, Volhynia and Podilia. Among them wooden and stone sacral buildings in Vinnytsia, Polonne, Chuduniv, Trypillia and many other Ukrainian cities and villages. His scientific intelligence H. Pavlutskyi built on the problem-chronological principle. The article specifies the features that attracted the researcher's attention, such as the type of construction, the period of construction, etc.

It is underlined, that H. Pavlutskyi was involved into the work of writing the multivolumed «The History of Russian Art»».

The author finds that the results of $H$. Pavlutskyi's researches in different years were presented at the meetings of Nestor the Chronicler Historical Society, archaeological congresses and other scientific forums.

H. Pavlutskyi derives the origin of Southern Russian church architecture from Byzantine traditions, but being creatively transformed for several centuries by local architects, who by using local building material created a unique, original architectural style.

The author affirms that the plans of the churches drawn by H. Pavlutskyi and their unique photographs make his work a valuable historical source. And as such, they are relevant to modern historical science.

Key words: Church building, architecture, temple, sacred building. 
Елена БОГАТИКОВА,

аспирантка Мариупольского государственного университета

(Украина, Мариуполь) lol9877@теta.иа

\title{
ИСТОРИЯ УКРАИНСКОГО САКРАЛЬНОГО СТРОИТЕЛЬСТВА В ИССЛЕДОВАНИЯХ ГРИГОРИЯ ПАВЛУЦКОГО
}

\begin{abstract}
В статье дана характеристика основных работ Г. Павлуцкого, посвященньх деревянному и каменному церковному зодчеству южнорусского региона. Установлены памятники архитектуры, которые попали в поле зрения ученого. Указаны их особенности, которые привлекли внимание исследователя: тип сооружения, период строительства. Акцентировано внимание на выводах, сделанных Г. Павлуцким об аутентичном происхождении сакральной архитектуры региона и времени строительства первых культовых сооружений. Указано на актуальность исследований Г. Павлуикого для современной науки.
\end{abstract}

Ключевые слова. Церковное зодчество, архитектура, храм, сакральное сооружение.

Постановка проблеми. Наша держава успадкувала від пройдешніх століть унікальний, неповторний скарб - пам'ятки дерев'яного сакрального зодчества. За підрахунками сучасних дослідників в Україні зберіглося понад 2,5 тис. дерев'яних церков, з яких близько 1000 відносяться до XV - XVIII ст. Окрім цього, на прилеглих етнічних українських землях їх налічується ще близько півтисячі. Але, за підрахунками Р. Маньковської, на облік та під охорону взято трохи більше 18 \% існуючих пам'яток. Розглядаючи дерев'яні церкви, розташовані не лише на території України, але й сучасних Польщі та Словаччини, дослідниця відмічає унікальність цих храмів, що стали звершенням не лише української але й світової культури.

Спираючись на дослідження вчених XIX ст., пам’яткоохоронний досвід, теоретичні напрацювання в царині сакрального будівництва, Р. Маньковська переконана, що сучасна українська наука формує засади створення архітектурної охоронно-реставраційної галузі, що дасть можливість відродити і зберегти історико-культурну спадщину України (Маньковська, 2010: 77-78, 83). Саме тому тема обраного дослідження є на сьогодні досить актуальною.

Аналіз досліджень. Інтерес вітчизняних науковців до пам’яток старовинної архітектури почав зростати ще наприкінці позаминулого століття. У цей період М. Каманін, М. Стороженко, М. Біляшівскьий, М. Істомін, Г. Павлуцький та ін. почали активно вивчати пам'ятки старовинного зодчества, у тому числі і сакрального. Наполегливу науково-дослідницьку роботу у цьому напрямку проводив Г. Павлуцький (1861 - 1924) - український вчений, викладач, громадський діяч.

Незважаючи на високий статус Григорія Григоровича в українському науковому та громадському житті, його постать досі залишається малодослідженою. Життєвий шлях вченого простежили І. Удріс, В. Туркевич, В. Афанасьєв, В. Пучков, М. Колісник та ін. Наприкінці 1990-х рр. Н. Ковпаненко зверталася до біографії вченого, досліджуючи історіографію вивчення пам'яток монументального мистецтва.

Отже, аналізу наукового доробку Г. Павлуцького не було приділено належної уваги. Тож, головний меседж сучасних науковців у тому, що хоча постать Григорія Григоровича і посідає помітне місце у вітчизняній науці, все ж його біографія мало досліджена.

Мета статті - проаналізувати дослідження Г. Павлуцького стосовно історії українського сакрального будівництва.

Виклад основного матеріалу. Свій шлях у науку Г. Павлуцький розпочав із дослідження античного мистецтва, проте згодом його наукові інтереси трансформувались у бік дослідження вітчизняної архітектури, зокрема церковної. Цьому посприяла, на думку сучасних вчених, його участь у роботі XI Археологічного з'їзду, який проходив у Києві 1899 р.

По завершенню роботи форуму при Історичному товаристві Нестора Літописця було створено «Комісію для опису старожитностей України», діяльність якої мала розгорнутися на території Київської, Чернігівської, Полтавської, Волинської та Подільської губерній. До ії складу разом із іншими членами Товариства увійшов і Г. Павлуцький. При цьому дослідники наголошують на значній роботі, проведеній саме останнім щодо розшуку і фіксації пам'яток архітектури та монументального мистецтва (Ковпаненко, 2008: 104). 
Влітку 1903 р. університет Св. Володимира відрядив Г. Павлуцького для дослідження старожитностей півдня Російської імперії. Розпочавши роботу над цією проблемою 1903 р., Г. Павлуцький присвятив їй не один рік свого життя.

Вирішивши проводити характеристику старожитностей за їх характером, а не за місцем розташування, Г. Павлуцький значну увагу приділив дерев'яним церквам XVII і XVIII ст., мотивувавши свій вибір тим, що ці пам'ятки більше за інших приречені на загибель. 3 цією метою дослідник обстежив деякі села, містечка та міста у трьох губерніях: Київській, Подільській та Волинській, зробив обміри, плани, розрізи розташованих у них церков.

Під час експедиції Г. Павлуцький обстежив 34 православні церкви, з них 7 - у Київській губернії, 16 - у Вінницькій та 11 - у Подільській, а також 3 католицьких храми у Волинській (церква Св. Анни - м. Полонне Новоградволинського повіту; церква Обретіння Чесного Хреста - м. Чуднов, Житомирського повіту) та Подільської (церква Св. Трійці - м. Зеньків Летичівського повіту) губерній (Павлуцький, 1905: 1).

Усі матеріали, зібрані й опрацьовані Г. Павлуцьким протягом багатьох років напруженої роботи, частково у співавторстві з іншими членами Історичного товариства Нестора Літописця Ю. Сіцинським, М. Біляшівським та В. Щербаківським, були оприлюднені на сторінках «Чтєній Історичного товариства Нестора Літописця», Трудів XIII, XIV та XV Археологічних з’їдів; у публікації «Каменные и деревянные храмы», вміщеній у першому, але й останньому, випуску «Древностей Украины» (1905) та узагальнюючій праці «О происхождении форм украинского деревянного церковного зодчества» (1911). Завдання, яке ставив перед собою дослідник, полягало не стільки в механічному відтворенні архітектурного ансамблю малоросійських храмів, скільки в його аналізі та щодо встановлення витоків українського сакрального зодчества: «Звідки ж з'явилася українська дерев'яна архітектура?» (Ковпаненко, 2014: 1). Окрім того, дослідник опрацював історію виникнення, релігійної діяльності кожної окремо взятої церкви, і все це на тлі історичних подій, яким він теж приділив чимало уваги. Почасти його праці перевантажені матеріалами місцевої історії, а безпосередньо темі дослідження відведено значно скромніше місце.

Найвизначнішою з-поміж праць Г. Павлуцького щодо українського сакрального зодчества XVII - XVIII ст. є нарис «Каменные и деревянные храмы». Це перша у вітчизняній науці спроба історичного опису та аналізу окремого виду національного мистецтва на основі вивчення архівних джерел, літератури та, найголовніше, значного фактичного матеріалу (Ковпаненко, 2005: 121). Слід відзначити, що праця Г. Павлуцького завдяки унікальним фотознімкам та планам церков, більшість яких не збереглися до XXI ст. представляє неабияку цінність для сучасних дослідників архітектурних пам'яток України XVII - XIX ст.

Дослідження складається з передмови та 19 розділів, кожен з яких містить опис одного або декількох храмів; 2 розділи автор присвятив характеристиці монастирів: Медведівського, Миколаївського та Мотронинського в Чернігівському повіті Київської губернії (Павлуцький, 1905: 2-12).

Дослідження Г. Павлуцького порушує одне з дискусійних питань, яке хвилювало думку провідних українських науковців XIX ст.: чи існує національний феномен української архітектури, зокрема церковної? Услід за іншими дослідниками - О. Новицьким, М. Русовим, О. Сластьоновим, В. Стасовим та ін. - Григорій Григорович наголошує на самобутності української архітектури (Гончаренко, 2000: 10-11).

Як зауважив Г. Павлуцький, наприкінці XIX ст. активно студіювались пам'ятки дерев'яної архітектури Півночі Російської імперії, які давали уявлення про церковний стиль XVIII ст. північних губерній, тоді як «південно-російський» архітектурний стиль залишався майже невідомим і «недовивченим» (Ковпаненко, 2013: 128). Тож, на сторінках свого дослідження науковець ретельно описує зовнішній вигляд церков та їх планову будову. Г. Павлуцький виділив декілька типів храмів, характерних для південно-західного регіону: однокупольний, трикупольний, п'ятикупольний. Окремо дослідник виділив храми хрестообразного плану з одним куполом у центрі хреста (ЧІТНЛ, 1905: 9-10).

Г. Павлуцький висловлює власне бачення стосовно часу виникнення, походження та характеру малоросійської церковної архітектури. Дослідник схильний датувати появу храмів описуваного типу XI ст. Задля підтвердження своєї гіпотези щодо часу та автентичності походження малоро- 
сійських храмів Г. Павлуцький звертається до вивчення історичних джерел: літописів XI - XV ст. (Радзивіловський або Кенігсберський літопис, Ізборнік великого князя Святослава (1073 р.)), де знаходить багато зображень трьохглавих та п'ятиглавих храмів.

Вказуючи на первинний влив візантійських традицій церковного будівництва, Г. Павлуцький відзначає його подальший самостійний розвиток, появу власних оригінальних особливостей. Дослідник не схильний зараховувати малоросійські храми до жодного зі стилів, вони, на його думку, самі є окремим стилем, що природно виник із будівельного матеріалу і залишався незмінним упродовж століть.

Аналізуючи старовинне дерев'яне зодчество на теренах України, Г. Павлуцький вперше спробував опрацювати генезу цієї архітектури, визначити іiї типові особливості, ступінь самобутності й певної залежності від сторонніх впливів. Стверджуючи дуже давнє походження української архітектури, учений пов'язав основні риси храмових форм з місцевими природними умовами та народними естетичними смаками. Думка про дерев'яне церковне будівництво як «період народної художньої творчості» стала головною в його оцінюванні пам'яток. Здійснюючи порівняльно-історичний аналіз зодчества України з дерев'яним будівництвом півночі Російської імперії, а також країн Свропи та Сходу, Г. Павлуцький висвітлив їх стилістичні відмінності й наголосив на самобутності, національному характері української архітектури, що залишалася незмінною протягом багатьох століть. Розглянувши низку середньовічних образотворчих джерел, учений дійшов висновку, що традиції українського дерев'яного зодчества почали формуватися ще за часів Київської Русі (Ковпаненко, 2013: 128-129).

Слід відзначити, що на пропозицію Імператорського Російського археологічного товариства видання «Древности Украины. Каменные и деревянные храмы» у 1906 р. було нагороджено великою срібною медаллю. На думку Н. Ковпаненко, дослідження Г. Павлуцького стало помітною подією в українській історичній науці. В умовах Російської імперії воно започаткувала спеціальну серію видань, присвячених художній спадщині України (Ковпаненко, 2014: 257-271).

Висновки стосовно початку будівництва церков у південно-західному краї, теорій походження південно-західного дерев'яного церковного зодчества, діяльності церков та монастирів тощо, зроблені Григорієм Григоровичем на сторінках вказаної праці, повторюються у його доповідях на засіданнях Історичного товариства Нестора Літописця, зроблених у різний час протягом $1904-$ 1906 рр. («Наиболеее ранние свидетельства литературных памятников о построении деревянных церквей XVII и XVIII вв.», «О деревянных резных изображениях путтов в южно-русских церквях XVII - XVIII вв.», «Изображение храма в древнейших южно-русских миниатюрах», «Памятники церковной каменной архитектуры стиля «етріге» в Полтавской губ.») та на XIII (Катеринослав, 1905) і XIV (Чернігів, 1908) Археологічних з'їдах.

Так, на одному із засідань ІТНЛ, у листопаді 1903 р., Г. Павлуцький оприлюднив результати свого дослідження матеріалу, зібраного членами Комісії з опису старожитностей України «Дерев'яна церковна архітектура у Південно-західному краї у XVII - XVIII ст.». У своїй доповіді дослідник виділив основні вектори у дослідженні архітектури регіону, а саме доцільність паралельного вивчення особливостей південно- та північно-руської архітектури; особливостей «малоруських церковних будівель»; походження сакральної архітектури регіону.

Розглядаючи паралельно північне і південне сакральне зодчество, Г. Павлуцький аж ніяк не схильний їх ототожнювати. Стосовно ж походження архітектурних стилів дослідник зауважує, що не зважаючи на те, що південноросійська та північноросійська архітектури надихаються чужими формами і взаємно впливають одна на одну, їх в жодному разі не можна назвати лише копіювальними; руські майстри не копіювали сліпо західні зразки, а переробляли їх власним розумом та серцем, у їхньому мистецтві панувала творча сила, котра і зробила дерев’яне зодчество півдня та півночі Росії оригінальним зображенням творчого генія.

Ретельно проаналізувавши всі наявні матеріали, Г. Павлуцький дійшов висновку, що, по-перше, «... малоруський архітектурний тип самостійно існував у Російській імперії з дуже давніх часів ...»; по-друге, «... на південно-руське і північно-руське дерев’яне зодчество слід розглядати як дві гілки одного і того ж мистецтва, котрі тільки згодом, роз'єднані політичним життям того та другого краю, зазнали деяких змін» (Павлуцький, 1904: 21-24). 
Інтерес представляє розвідка Г. Павлуцького щодо церковних будівель стилю «етріге» у Полтавській губернії. Дослідник назвав вісім пам’ятників цього стилю: Миколаївська, соборна Успенська та Воскресенська церкви у м. Хоролі, Троїцька церква у с. Вишняках, Миколаївська (м. Ромни), дві церкви в селах Сньках та Вергунах Хорольського повіту та церква в м. Лубнах, зазначивши при цьому, що «в Полтавській губернії всі храми стилю «етріre» замінили собою старовинні дерев’яні церкви малоросійського стилю».

Особливості стилю Г. Павлуцький прослідкував на прикладі двох дуже схожих між собою церков - соборної Успенської та Воскресенської у м. Хоролі: соборна церква «має ліпні прикраси античного зразка: всередині цієї церкви зверху по стінах і в куполі; на капітелі пілястрів і на барабані купола; круглі великі скульптурні розетки на стінах портиків, великі вази у нішах на зовнішніх стінах тощо. ....у цих храмах стилю «етріrе» передню частину фасаду утворює портик 3 доричними колонами; такі портики встановлювалися $з$ трьох боків: 3 півночі, півдня та заходу; нижня частина стіни оброблена рустами, верхня - гладка; колони, грустики, купол - яйцевидної форми на зразок купола собору св. Петра в Римі...доричні колони часто не мають баз - це риса руського «етріre»» (Павлуцький, 1906: 94-97).

Слід наголосити, що свої напрацювання в царині сакральної архітектури південно-західного краю Г. Павлуцький також неодноразово представляв під час роботи Археологічних з'їздів. Так на засіданнях XIII АЗ Г. Павлуцький уперше порушив питання про необхідність вивчення київської архітектури XVII - XVIII ст. як національної художньої школи, рівної за значенням зодчеству княжої Русі. У своїх доповідях, зроблених під час роботи з'їзду, дослідник висвітлив історію дерев'яного зодчества в Україні, охарактеризував своєрідність пам'яток Лівобережної України (Ковпаненко, 2008: 106).

Важливе значення для розвитку студій архітектурної спадщини України мала, на думку Н. Ковпаненко, значна за обсягом доповідь Г. Павлуцького «Про вплив дерев’яного церковного зодчества на архітектурні форми мурованих храмів в Києві XVII - XVIII ст.». У ній чи не вперше було порушено питання про необхідність поглибленого вивчення мурованої київської архітектури доби Гетьманщини, пам'ятки якої до того часу майже не привертали науковців. Вирізняючись особливою оригінальністю, відбиваючи риси епохи й маючи яскраві ознаки національної художньої школи, ця архітектура, на глибоке переконання вченого, потребувала наукового опрацювання не менше, ніж зодчество Київської Русі. Реферат містив поданий на широкому історичному тлі стилістичний нарис загальної історії церковного будівництва в Києві з найдавніших часів до XVIII ст. включно. Основні положення доповіді Г. Павлуцького були підтримані науковцями.

Тему української сакральної архітектури Г. Павлуьцкий продовжував і пізніше. Останнім містом в Україні, де відбувся черговий XIV Археологічний з’їзд, був Чернігів (Ковпаненко, 2013: 209-211; 213). Під час роботи Археологічного з’їзду, який проходив 31 по 15 серпня 1908 р., Г. Павлуцький представив кілька доповідей: «Київські храми домонгольського періоду та їх приналежність до візантійського зодчества», «Про походження форм дерев’яного церковного зодчества», «Про церковні споруди у стилі Еmріге у Полтавській губернії» (Красніцька, 2011: 64).

Н. Ковпаненко зазначає, що на XIV Археологічному з'їзді чи не вперше отримали наукову розробку питання української архітектурно-мистецької спадщини пізніших періодів. I виступ Г. Павлуцького був присвячений мурованим церквам і храмам Полтавщини кінця XVIII - початку XIX ст., зведеним у стилі ампір. Як і в інших своїх працях, крім глибокого аналізу окремих пам'яток, науковець подав яскраву характеристику історичної епохи, за якої вони були створені (Ковпаненко, 2013: 219).

XV Археологічний з'їзд проходив у Новгороді з 22 липня по 04 серпня 1911 р. Усього під час роботи форуму відбулося 32 засідання, на яких було представлено 90 доповідей, 40 з яких були присвячені історії та старожитностям Новгорода.

Г. Павлуцький, як один із учасників з'їзду, також не оминув увагою означену тему. Як стверджує Н. Полонська-Василенко, у своїй доповіді «Про візантійські риси у декоративній обробці фасадів Новгородських храмів XI - XIV ст.» дослідник доводив, що зовнішній вигляд новгородських храмів запозичений із візантійського мистецтва. Прикладом цього впливу він вважав тре- 
тинний поділ стінки аркою з двома напів-арками, причому арка трансформувалася із потрійного візантійського вікна.

В іншій своїй доповіді - «Один із впливів західно-європейського мистецтва на північне дерев'яне церковне зодчество», Г. Павлуцький вказував, що вітчизняні храми, у формі кубу з п'ятьма главками, запозичили ці главки з готичного мистецтва Англії, Чехії та Угорщини із замкових башт (Полонська, 1912: 11; 13).

Розвідки Г. Павлуцького щодо церковної архітектури південноросійського краю вміщено також і у багатотомному виданні «История русского искусства» I. Грабаря. Проте, якщо свою статтю «Деревянные и каменные храмы» дослідник присвятив аналізу сільських та містечкових церков XVII - XIX ст., то у статті, вміщеній в «Истории русского искусства» він звернувся до сакральних пам'яток Києва та Чернігова XI ст. Григорій Григорович наголосив на тому, що «всі вцілілі до нас пам'ятки великокняжої епохи в Південній Росії носять на собі сліди візантійської роботи: всюди ми бачимо візантійську техніку та візантійські художні прийоми» (Павлуцький, 1909: 143-162).

Підсумком багаторічної плідної праці Г. Павлуцького можна вважати нарис «О происхождении форм украинского деревянного церковного зодчества» (1911), на сторінках якого автор ще раз доводить існування дерев'яних православних церков на території України (Київської Русі) ще в домонгольський період (XI - XII ст.): «...дерев’яні церкви, котрі...тягнуться безперервно від епохи Володимира Св. До другої половини XVIII ст., утворюючи один суцільний ланцюг, - можна вважати, що основні риси українського архітектурного церковного стилю повинні сягати сивої давнини, а саме домонгольського періоду» (Павлуцький, 1911: 2).

Треба підкреслити, що майже всі наукові праці Г. Павлуцького з питань історії вітчизняної архітектури мають певні особливості. 3 одного боку, у кожній роботі автора виявляється певна зацікавленість популярною на той час теорією впливів. Простежується прагнення виявити взаємозв'язок національних традицій будівництва з традиціями інших епох і народів. Водночас учений не відхиляється від головного напрямку - пошуку національної своєрідності, неповторності українських пам'яток від домонгольської доби і до наших часів. В оцінках пам'яток архітектури давньослов'янського Києва та Чернігова, храмів Прикарпаття то споруд українського бароко відчувається обгрунтована впевненість автора у високих художніх якостях національного мистецтва, що дозволяють їм знайти своє місце на одному ступені з всесвітньо відомими пам'ятками архітектури Колісник, 2005: 42).

Н. Ковпаненко стверджує, що як учений універсалістського напрямку, прихильник теорії впливів, Г. Павлуцький у своїх працях прагнув виявити джерела тих чи інших національних художніх явищ, високо оцінював талант українського народу, який творчо трансформував певні культурно-художні запозичення відповідно до своїх смаків і потреб. Одним із перших він намагався визначити роль національної спадщини у світовому культурному процесі. Учений розглядав старовинну вітчизняну архітектуру як своєрідну національну школу серед інших європейських шкіл, а відтак як повноправну складову загальнолюдської художньої культури. Створена Г. Павлуцьким концепція розвитку української архітектури, викладена ним у другому томі «Історії російського мистецтва», відіграла помітну роль в обговоренні одного з провідних питань тогочасного українського мистецтвознавства й архітектурно-художньої практики - проблеми визначення національного стилю, тобто виявлення й утвердження національної своєрідності художньої спадщини українського народу, що відбувалось особливо інтенсивно упродовж 1912 - 1913 рр. (Ковпаненко, 2013: 131-132).

Висновки. Таким чином, Григорій Григорович у своїх дослідженнях зумів вдало поєднати історію південноросійського краю з історією церковного будівництва, дав детальний аналіз кожної споруди, виділив три типи храмових будівель, характерних для даного регіону. Крім того, його праці містять накреслені плани церков та фотографії більшості з них, що у XXI ст. робить їх також і цінним історичним джерелом. Спираючись на широкий фактичний матеріал та роботи попередників Г. Павлуцький доводить автохтонне походження культової архітектури регіону. 


\section{СПИСОК ВИКОРИСТАНИХ ДЖЕРЕЛ І ЛІТЕРАТУРИ}

Гончаренко, 2000 - Гончаренко М. Становлення історичних досліджень архітектури України (кінець XIX - початок XX ст.): автореф. дис. на здобуття наук. ступеня канд. архітектури: спец. 18. 00. 01 «Теорія архітектури, реставрація пам'яток архітектури». Киїі. 2000. 21 с.

Ковпаненко, 2013 - Ковпаненко Н. Архітектурно-мистецька спадщина Наддніпрянської України у вітчизняних історичних дослідженнях (кінець XIX - початок XX ст.). Київ, Інститут історії України НАН України, 2013, 309 с.

Ковпаненко, 2005 - Ковпаненко Н. Архітектурно-мистецька спадщина України в працях визначних учених другої половини XIX - початку XX ст. // Український історичний журнал. 2005. № 6. С. 112-128.

Ковпаненко, 2008 - Ковпаненко Н. Роль археологічних з'їздів останньої третини XIX - початку XX ст. у дослідженні архітектурно-мистецької спадщини України // Український історичний журнал. 2008. № 6. C. $99-110$.

Ковпаненко, 2014 - Ковпаненко Н. Дослідження національної архітектурно-мистецької спадщини у діяльності Історичного товариства Нестора-Літописця (1900-ті pp.) // Україна XX ст.: культура, ідеологія, політика. Збірник статей / Відп. ред. В. Даниленко. 2014. Вип. 19. С. 257-271.

Колісник, 2005 - Колісник Є. Павлуцький Г. Г. як дослідник вітчизняної архітектури // Вісник Харківської державної академії дизайну і мистецтв. 2005. №2. С. 36-41.

Красніцька, 2011 - Красніцька Н. Григорій Павлуцький - дослідник українського та світового народного мистецтва // Етнічна історія народів Свропи. 2011. Вип. 35. С. 62-67 [Електронний ресурс]. Режим доступу: http://www.history.univ.Kiev.ua/ethnologi/journal/ethnic_history_35/35_10.pdf.

Маньковська, 2010 - Маньковська Р. Сакральна дерев'яна архітектура України у світовій спадщині // Краєзнавство. 2010. №4. С. $77-86$.

Отчет, 1912 - Отчет о состоянии и деятельности Исторического общетсва Нестора летописца в 40-м году его существования, с 27 октября 1911 г. по 27 октября 1912 г. // ЧИОНЛ. 1912.

Павлуцкий, 1904 - Павлуцкий Г. Деревянная церковная архитектура Юго-Западного края в XVII и XVIII вв. // Чтения в Историческом обществе Нестора Летописца. 1904. Кн. 18. Вып. 1. С. 21-24.

Павлуцкий, 1905 - Павлуцкий Г. Деревянные и каменные храмы // Древности Украины. Вып.1. Киев: Издание Императорского Московского Археологического общества. 1905. 124 с.

Павлуцкий, 1906 - Павлуцкий Г. Памятники церковной каменной архитектуры стиля «етріre» в Полтавской губ. // Чтения в Историческом обществе Нестора Летописца. 1906. Кн.19. Вып. 4. С. 94-97.

Павлуцкий, 1909 - Павлуцкий Г. Древнейшее каменное зодчество // История русского искусства: Архитектура. Т. 1. История архитектуры: Допетровская єпоха. Москва. 1909. С. 143-162.

Павлуцкий, 1911 - Павлуцкий Г. О происхождении форм украинского деревянного церковного зодчества. Москва: Типография Г. Лиссинкра и Д. Совко. 1911. 20 с.

Полонская, 1912 - Полонская Н. Великий Новгородъ и XV археологический съезд. Киев: Тип. Киев. военного округа. 1912. 16 с.

\section{REFERENCES}

Honcharenko, 2000 - Honcharenko M. Stanovlennia istorychnykh doslidzhen arkhitektury Ukrainy (kinets XIX - pochatok XX st.) [The formation of historical studies of architecture of Ukraine (the end of the XIX and the beginning of the XX century)]: avtoref. dys. na zdobuttia nauk. stupenia kand. arkhitektury: spets. 18.00 .01 «Teoriia arkhitektury, restavratsiia pamiatok arkhitektury». Kyiv, 2000. 21 s. [in Ukrainian].

Kovpanenko, 2005 - Kovpanenko N. Arkhitekturno-mystetska spadshchyna Ukrainy v pratsiakh vyznachnykh uchenykh druhoi polovyny XIX - pochatku XX st. [Architectural and artistic heritage of Ukraine in the writings of prominent scholars of the second half of the XIX and early XX centuries.] // Ukrainskyi istorychnyi zhurnal. Kyiv, 2005. № 6. S. 112-128. [in Ukrainian].

Kovpanenko, 2008 - Kovpanenko N. Rol arkheolohichnykh zizdiv ostannoi tretyny XIX - pochatku XX st. u doslidzhenni arkhitekturno-mystetskoi spadshchyny Ukrainy [The role of archaeological congresses of the last third of the XIX and early XX centuries. in the study of the architectural and artistic heritage of Ukraine] // Ukrainskyi istorychnyi zhurnal. Kyiv. 2008. № 6. S. 99-110 [in Ukrainian].

Kovpanenko, 2013 - Kovpanenko N. Arkhitekturno-mystetska spadshchyna Naddniprianskoi Ukrainy u vitchyznianykh istorychnykh doslidzhenniakh (kinets XIX - pochatok XX st.) [Architectural and artistic heritage of the Dnieper Ukraine in the national historical researches (the end of the XIX and the beginning of the XX century)]. Kyiv. Instytut istorii Ukrainy NAN Ukrainy. 2013. 309 s. [in Ukrainian].

Kovpanenko, 2014 - Kovpanenko N. Doslidzhennia natsionalnoi arkhitekturno-mystetskoi spadshchyny u diialnosti Istorychnoho tovarystva Nestora-Litopystsia (1900-ti rr.) [Research of the national architectural and artistic heritage in the activities of the Historical Society of the Nestor-Chronicler (1900's).] // Ukraina XX st.: 
kultura, ideolohiia, polityka. Zbirnyk statei / Vidp. red. V. Danylenko. Kyiv. Instytut istorii Ukrainy Natsionalnoi akademii nauk Ukrainy, 2014. Vyp. 19. S. 257-271. [in Ukrainian].

Kolisnyk, 2005 - Kolisnyk Ye. Pavlutskyi H. H. yak doslidnyk vitchyznianoi arkhitektury [Pavlutskiy G. G. as a researcher of domestic architecture] // Visnyk Kharkivskoi derzhavnoi akademii dyzainu i mystetstv. Kharkiv. 2005. № 2. S. 36-41. [in Ukrainian].

Krasnitska, 2011. - Krasnitska N. Hrhorii Pavlutskyi - doslidnyk ukrainskoho ta svitovoho narodnoho mystetstva [Grigory Pavlutskiy is a researcher of Ukrainian and world folk art] // Etnichna istoriia narodiv Yevropy. 2011. Vyp. 35. S. 62-67 [Elektronnyi resurs]. Dostupnyi z: http://www.history.univ.Kiev.ua/ethnologi/journal/ ethnic_history_35/35_10.pdf [in Ukrainian].

Mankovska, 2010 - Mankovska R. Sakralna dereviana arkhitektura Ukrainy u svitovii spadshchyni [The sacred wooden architecture of Ukraine in the world heritage] // Kraieznavstvo. Kyiv. 2010. № 4. S. 77-86. [in Ukrainian].

Otchet, 1912 - Otchet o sostoianii y deiatelnosti Istorycheskoho obshchetsva Nestora letopistsa v 40-m hodu eho sushchestvovaniia, s 27 oktiabria 1911 h. po 27 oktiabria 1912 h. [Report on the status and activities of the Historical Society of Nestor the Chronicler in the 40th year of his existence, from October 27, 1911 to October 27, 1912] // ChYONL. Kyiv. 1912. [in Russian].

Pavlutskiy, 1904 - Pavlutskiy G. Dereviannaia tserkovnaia arkhytektura Yuho-Zapadnoho kraia v XVII y XVIII vv. [Wooden church architecture of the South-Western Territory in the XVII and XVIII centuries.] // Chtenyia v Istorycheskom obshchestve Nestora Letopystsa. Kiev. 1904. Kn. 18. Vyp. 1. S. 21-24. [in Russian].

Pavlutskiy, 1905 - Pavlutskiy G. Dereviannye i kamennyie khramy [Wooden and stone churches] // Drevnosti Ukrainy. Vyp. 1. Kiev. Izdanie Imperatorskoho Moskovskoho Arkheolohicheskoho obshchestva. 1905. 124 s. [in Russian].

Pavlutskiy, 1906 - Pavlutskiy G. Pamiatniki tserkovnoi kamennoi arkhytektury stoletia «empire» v Poltavskoi hub. [Monuments of church stone architecture of the «empire» style in Poltava province] // Chtenyia v Istorycheskom obshchestve Nestora Letopystsa. Kiev. 1906. Kn. 19, Vyp. 4. S. 94-97. [in Russian].

Pavlutskiy, 1909 - Pavlutskiy G. Drevneishee kamennoe zodchestvo [The most ancient stone architecture] // Istoryia russkoho iskusstva: Arkhytektura. T. 1. Istoryia arkhytekturi: Dopetrovskaia epokha. Moskva. 1909. S. 143162. [in Russian].

Pavlutskiy, 1911 - Pavlutskiy G. O proyskhozhdenyy form ukraynskoho dereviannoho tsnrkovnoho zodchestva [On the origin of forms of Ukrainian wooden architecture] Moskva: Typohrafyia H. Lyssynkra i D. Sovko. 1911. 20 s. [in Russian].

Polonskaya, 1912 - Polonskaya N. Velykyi Novhorod i XV arkheolohycheskyi sezd [Great Novgorod and XV archaeological congress]. Kiev. Tip. Kiev. voennoho okruha. 1912. 16 s. [in Russian].

Стаття надійшла до редакиії 10.02.2018 p. 